Journal of Indonesian Economy and Business

Volume 34, Number 1, 2019, 37- 59

\title{
TEENS AND THE HANG OUT LIFESTYLE: WHAT DRIVES TEENS SATISFACTION AND ATTITUDINAL LOYALTY?
}

\author{
Risca Fitri Ayuni* \\ Department of Management, Faculty of Economics and Business, Universitas Brawijaya, \\ Malang, 65145, Indonesia
}

\begin{tabular}{|c|c|}
\hline ABSTRACT & ARTICLE INFO \\
\hline $\begin{array}{l}\text { Introduction: Satisfying teens consumer group is critical to retain a } \\
\text { larger market share in the future. Creating teens' experience and value } \\
\text { seems to be fundamental for enhancing both satisfaction and loyalty in } \\
\text { cafes industry. Background Problem: This study examines the impact of } \\
\text { customers' experiences and the hedonic quality on teenagers' satisfaction } \\
\text { and attitudinal loyalty. Novelty: This study provides a new and } \\
\text { comprehensive model of customer experience by adding hedonic value as } \\
\text { a subjective experience to evaluate satisfaction and attitudinal loyalty. } \\
\text { Research Method: Questionnaires were used to collect the data. } \\
\text { Purposive sampling was chosen to select the respondents. Two hundred } \\
\text { Indonesian teens participated in this study. In order to achieve the aim of } \\
\text { this study, SPSS } 23 \text { and Partial Least Square (PLS) } 3 \text { were used. Seven } \\
\text { out of ten hypotheses proposed in the study were supported. Findings: } \\
\text { Three dimensions of customer experience (staff interaction, customer } \\
\text { interaction and physical environment) have a significant effect on } \\
\text { customers' satisfaction, but only one dimension (physical environment) } \\
\text { has an effect on customers' attitudinal loyalty. An additional finding of } \\
\text { this research is that all the hedonic quality dimensions (except hedonic } \\
\text { emotional) have an effect on customers' satisfaction. Lastly, customers' } \\
\text { satisfaction has a significant effect toward customers' attitudinal loyalty. } \\
\text { Conclusion: The findings suggested that a cafe's manager or owner } \\
\text { should pay attention to their customers' experiences and their hedonic } \\
\text { quality, in order to create customer satisfaction and enhance their } \\
\text { attitudinal loyalty toward the cafe. }\end{array}$ & $\begin{array}{l}\text { Article history: } \\
\text { Received } 1 \text { October } 2017 \\
\text { Received in revised form } \\
7 \text { December } 2017 \\
\text { Received in revised form } \\
7 \text { May } 2018 \\
\text { Received in revised form } \\
\text { 29 January } 2019 \\
\text { Accepted } 15 \text { April } 2019\end{array}$ \\
\hline
\end{tabular}

\footnotetext{
* Corresponding Author at Department of Management, Faculty of Economics and Business, Universitas Brawijaya, Malang, 65145, Indonesia

E-mail address: Risca.fa@ub.ac.id (author),
} 


\section{INTRODUCTION}

The number of teenagers worldwide is predicted to rise by $7 \%$ (to 1.3 billion in 2030). The UN states that Asia will have more teenagers than any other region until 2080 (United Nations, 2015). The rapid growth of the teenage population implies a big challenge and an opportunity for several industries, since teenagers are their potential market. According to Chadwick (2017), teenagers are the main influencers in households, whose opinion and preference for purchases is heeded by their parents. In other words, family spending is highly influenced by teenagers.

Understanding teens' behavior in consuming a product is the best way to retain a larger market share in the future. By satisfying them, it is possible for industries to control their future purchase behavior, including their willingness to engage in repeat buying and to recommend the product to others. Empirically, there is a consensus among scholars that satisfaction is a salient business goal and a key to obtaining loyalty (Kim, Li, \& Brymer, 2016; Ryu et al., 2012).

As an important concept in marketing, loyalty promises a greater market and profit. Loyalty can be categorized into two perspectives: behavioral and attitudinal. (Baloglu, 2002, Guest, 1955; Jacoby, 1971; Assael, 2004).

Griffin, (2002) claimed that loyalty is a behavior, not an attitude. In contrast, Jacob (1971) placed attitudinal loyalty as a vehicle to drive behavioral loyalty. In other words, behavioral loyalty is affected by attitudinal loyalty as well as by the situation. This study is focusing on attitudinal loyalty as a requirement for another loyalty, behavioral loyalty.

Another aspect that needs to be considered in the catering business is experience (Josiam et al, 2004; Apfel, 1998; Ryu, and Han, 2011; Ariffin et al, 2012). From the marketing perspective, a good customer experience positively affects customers' satisfaction and triggers customer loyalty. Meyer and Schwager (2007) defined customer experience as a customer's internal and subjective response to the company, directly and indirectly.

In society, teenagers also play a pivotal role in setting new trends, such as lifestyle trends. Hanging out at a cafe is a new lifestyle that has been brought into by teens. Peterson (2017) and Ruggles (2017) reported that teenagers are spending about $24 \%$ of their money on food (café or restaurant), followed by clothing, cars, accessories, shoes and other products. The number is higher than for any other age group (Dugan, 2015). Thus, this phenomenon considers that teenagers are behaving in more hedonic consumption than other consumers, based on age.

In the context of the café, teenage customers consider that going to cafes is not only about ordering food or beverages, but also to fulfill their hedonic and symbolic pleasure motivations, as opposed to a utility function (Arnold and Reynolds (2003); Wakefield and Baker (1998). Holbrook and Hirschman (1982) characterized the products and services that are provided by travel, hotels, art, restaurants or cafes as being for hedonic consumption.

Hedonic consumption plays a more important role than utilitarian consumption, as the customer receives hedonic values in terms of the subjective experiences of fun and playfulness. They expect to have a feeling of pleasure when consuming goods or services (Holbrook, 1996, Holbrook and Hirschman, 1982; Babin et al., 1994)

About $17.9 \%$ of the Indonesian population (45.8 million) are teenagers (Widiadana, 2017). This number supports the recent mushrooming of cafes as a consequence of the change in 
teenagers' lifestyles in Indonesia. A considerable growth in the number of new cafes, both western-style cafes and local-style cafés, show a higher demand for cafes, which creates fierce competition among cafes.

In the past five years, the growth in the number of cafes in Indonesia has doubled (Chikoti, 2016). As the numbers grow, competition becomes tighter, and only a few cafes survive for more than one year. A study from Ohio State University in businessinsider.com pointed out that about $60 \%$ of cafes/restaurants failed before the first year and $80 \%$ go under in five years (Feloni, 2014; Bellini, 2016). Most of the cafes cannot survive the competition because the manager or owner lacks knowledge of what drives the satisfaction and loyalty of their customers (O’Dell, 2008), especially the teenage group if they are their major target.

Arnold and Reynolds (2003); Babin, et al. (1994); and Wakefield and Baker (1998) stated that the main reasons teens love to hang out at cafes is because cafes provided a cozy place to relieve their stress or to socialize with their friends. Moreover, those researchers found that the need for entertainment is the main reason for people to go out to eat, rather than cook themselves. In different fields (tourism, traveling, shopping), hedonic was described as one of the key dimensions of customer value (Jones et al, 2006 and Sanchez et al, 2006) and customer satisfaction (Jones et al, 2006; Yang et al, 2010; Berry and Wall, 2007; Kim and Moon, 2009; Ryu and Jang, 2007; Magnini and Parker, 2009)

In the tourism and hospitality industries, various studies proposed different elements for customer experience. Hemmington (2007) proposed the host-guest relationship, generosity, theater and performance, numerous small surprises, and safety and security. Four dimensions were proposed by Knutson, namely environment, accessibility, driving benefit, and incentive. Bitner (1992); Gupta and Vajic (1999), Walls (2013), Gupta and Vajic (1999); Grove, Fisk, and Dorsch (1998); Walls, Okumus, Wang, and Kwun (2011) identified the physical environment, customers' interaction with staff, and their interaction with other customers as elements of customer experience.

Most of the prior studies only identified customer experience as an internal customer response or subjective experience. There are no studies that combine both customers' internal and subjective responses to measure customer experience.

Finally, understanding these basic issues is likewise critical for the cafe manager. The current study provides a comprehensive model of customer experience by adding hedonic value as a subjective experience to evaluate satisfaction and attitudinal loyalty. Teens are recruited for the reason that teens will play a vital role in the future, particularly for cafes. Regarding the explanation above, the aim of this study is to assess the impact of customer experience and hedonic quality on teenagers' satisfaction and loyalty when hanging out at a cafe.

\section{LITERATURE REVIEW}

\section{Customer Experience}

Experience is generated when customers consume goods or products. Although its definition is very close to satisfaction, the experience is created before satisfaction is generated for the customer. Experience is an evaluation of the goods and service when the customer consumes them, and this could trigger satisfaction or dissatisfaction. Pine and Gilmore (1998) describe the experience as a dynamic thought from the individual's involvement, and the desire with which the individual associates or engages with the product or service. 
According to Meyer and Schwager (2007), customer experience was defined as a customer's internal and subjective evaluation when the customer comes in contact with the company, whether through direct or indirect contact.

Customer experience is commonly used by the hospitality business, such as hotels or tourism objects, most have found a significant effect from customers' experiences toward customers' satisfaction (Ali, et al., 2016; Teng, 2011; Pine and Gilmore, 1998). Some of the prior studies also find that a good customer experience could create customer loyalty (Hussein, et al., 2015; Lugosi, 2016; Skogland and Siguaw, 2004; Teng, 2011; Ali, et al., 2016; Bigne, et al., 2005; Collins, 2010; and Jalil, et al., 2016)

Prior literature proposed various components of the customer experience (Hemmington, 2007; Bitner, 1992; Gupta and Vajic, 1999; Walls, 2013, Gupta and Vajic, 1999; Grove, Fisk, and Dorsch, 1998; Walls, Okumus, Wang, and Kwun, 2011). Bitner (1992); and Gupta and Vajic (1999) proposed the physical environment and interaction as customer experience dimensions. Grove (1998) added the interaction of staff and customers as one of the customer experience dimensions. Recent studies that compiled those components as customer experience dimensions are Fisk, et al. (2004); Walls, et al. (2011); and Ali et al. (2014).

Collins (2010) added that the unique atmosphere of one cafe should be able to create a different ambiance from that of another cafe, thus providing a completly different experience for each customer.

The intimate relation between service provider/staff and the customers, including the physical environment, will affect the customers' experiences. Their experience reflects their feelings, action and thoughts on the events they experienced (human-product interaction) (Hassenzahl, 2008).

\section{a. Interaction with customers}

Hanging out at a cafe with friends and family will be more fun than if we do it alone. Some teens choose cafes as a place for socializing with others. Interaction among customers will occur during service delivery and will influence their satisfaction and loyalty (Ali et al, 2016, Kao et al.,2008; Mossberg, 2007; Brady and Cronin, 2001 Walls et al.,2011; Zeithaml et al.,2006). As they are served by the same provider at the same time, more customers might affect the quality of services and also the emotions of other customers. (Cetin and Dincer, 2014; Grove et al.,1998)

The impact of customers' contact with other customers can be classified in two ways: cognitive (how customers should behave) and affective (empathy among customers) (Huang \& Hsu, 2010; Tombs \& McColl-Kennedy, 2013). From the above, the following hypotheses are proposed:

H1: Interaction with customers positively affects attitudinal loyalty

H2: Interaction with customers positively affects teens' satisfaction

\section{b. Interaction with staff}

Interaction between customers and staff has been considered by previous researchers, since it has a big impact on satisfaction and loyalty (Slatten et al, 2011; Walls et al, 2011; Zeithaml et al, 2006; Loureiro, 2010; and Kao et al., 2008). Teens hang out at cafes expecting to have positive experiences provided by the staff.

Ali et al (2016) stated the characteristics of the staff could be the prime cause of the customers' experience and satisfaction, by providing a thorough and satisfactory service, 
while the staff must be reliable, professional and have a good knowledge of their products.

Even though prior studies have conducted research about the importance of interaction with staff, more research is worth undertaking.

H3: Interaction with staff positively affects attitudinal loyalty

H4: Interaction with staff positively affects teens' satisfaction

\section{c. Physical environment}

As a cafe is a part of the tourism and hospitality industries, and provides more hedonic consumption, providing a good setting for its physical facilities is beneficial for its customers when evaluating the café's services. Parasuraman et al (1988) described the physical environment as the tangible elements of intangible services. Bitner (1992) introduced three elements for the physical environment namely ambience, space orfunction, and signs/ symbols which are related to the five human senses.

Similarly, Han \& Ryu (2009) and Lin \& Liang (2011) stated that design, lighting, smell, temperature, facilities and layout are the main elements of a physical environment.

The physical environment plays an important role in shaping customer satisfaction (Ryu, Lee, and Kim, 2012; Li, Wong, \& Kim, 2016; Ali et al, 2016). Prior studies has proved that the physical environment has a big influence on customer satisfaction and loyalty (Dong \& Siu, 2012; Pareigis, Edvardsson, \& Enquist, 2011; Ariffin \& Yahaya, 2013; Ali et al, 2016).

For teens, as the main target customers of cafes, the physical environment is meaningful. In this social media era, teens show their existence by uploading attractive and unique photos of them in special spots. Mary et al (2013) surveyed that currently teens share more of their experiences, including photos of themselves, in their social media. More teens post photos in famous places, more teens will visit the same spots and take more pictures there. Therefore, a cafe manager must consider the physical environment, particularly the ambiance of the café, as it is more relevant for the café's business and will help the cafe attract more visitors.

In this research we will analyze this suggestion to confirm whether the physical environment of cafes could improve teens satisfaction and loyalty.

Based on the prior research and literature, the next hypotheses we proposed in this research are:

H5: Physical environment positively affects attitudinal loyalty

H6: Physical environment positively affects teens' satisfaction

\section{Hedonic Quality}

According to Poushneh and Vasquez (2017), its hedonic quality is a part of a product's attributes. Prior studies have shown that while users explicitly state their preference for new utilitarian features, their "true" preference is for the hedonic (Dhar and Wertenbroch, 2000; Astuti and Hanan, 2012; Diefenbach and Hassenzahl, 2011; Josiam and Henry, 2014; and Okada, 2005). This study focuses on the hedonic quality as it has a higher value for the customer than utility (Dhar and Wertenbroch, 2000; Diefanbach and Hassenzahl, 2011; and Okada, 2005).

Hedonic quality is defined as the value obtained by a consumer from finding and purchasing a particular good or service. This quality is different from the utilitarian quality (Chitturi et al, 2008) as it comes from the subjective experience of pleasure (fun and 
playfulness) when consuming goods or services (Holbrook, 1996, Holbrook and Hirschman, 1982; Babin et al., 1994).

Limited studies assessed hedonic quality as a part of the customers' experiences. Most studies only examined the internal customer response. By including hedonic quality as a subjective customer experience, it would provide comprehensive results for evaluating the customers' experiences. Hedonic quality can be distinguished into three types: by stimulation (HQ-S), by identification (HQ-I), and by evocation (HQE). HQ-S is related to the fulfillment of human needs for novelty and challenge. HQ-I refers to the fulfillment of human needs as selfexpression. HQ-E refers to a human's fulfillment needs for symbolic meanings in an object (Hassenzahl and Tractinsky, 2006).

Based on Hassenzahl and Tractinsky, Poushneh and Vasquez (2017) proposed three types of hedonic quality: hedonic quality by rational stimulation, hedonic quality by emotional stimulation and hedonic quality by identification. Creating hedonic quality for customers could improve the customers' satisfaction (Jones et al, 2006; Gallarza and Saura, 2006; Yang et al, 2010; Berry and Wall, 2007, Kim and Moon, 2009, Pullman and Gross, 2004, Pullman and Robson, 2007; Ryu and Jang, 2007; Magnini and Parker, 2009).

Furthermore, Jiang and Wang (2006) found that the hedonic aspect or utilitarian aspect was affected by pleasure and the perceived service quality. Interestingly, they also found that pleasure had a stronger effect on the perceived service quality and satisfaction in the hedonic aspect rather than the utilitarian aspect.

\section{a. Hedonic quality by emotional stimulation}

Positive experinces potentially evoke emotional consequences that lead to satisfaction and loyalty to a product (Hassenzahl, 2005; Desmet and Hekkert, 2007). When customers come into contact with a product/service, they will evaluate the advantages and disadvantages of consuming that product/service.

In the context of the hospitality industry (e.g café, hotel), it is hard to reach all the customers' emotions properly. Each customer has their own needs, motives, goals and other considerations when interacting with the services provided (Desmet \& Hekkert, 2007). Once these services can satisfy the customers' psychological needs, positive emotions and experiences will follow.

Hassenzahl and Tractinsky (2006) and Poushneh and Vasquez (2017) summarized service attributes that fulfill customers' emotions by describing whether the service is repellingappealing, discouraging-motivating, not absorbed-over absorbed, and not immerseimmerse.

A lack of teenage motivation, negative experiences and bad feelings while hanging out at a café are serious problems that result in barriers to satisfaction and loyalty. The main cause is not fulfilling the teens' emotional stimulation needs.

H7: Hedonic quality through emotional stimulation positively affects teens' satisfaction

\section{b. Hedonic quality by identification}

Social identity is one of the decisive factors in generating customer satisfaction and loyalty. Hedonic quality by identification is aimed at creating social identity and communicating identity (social impact) when customers have contact with a product/service (Hartson, Pardha, 2012).

The product consumed by people expresses who the customers are and how they are viewed by others (Hassenzahl et al, 2003; 2005). Moreover, Hassenzahl et al $(2003,2005)$ and Poushneh and Vasquez (2017) described the indicators to identification, including those that 
separate me from people-bring me closer to people, alienating-integrating, and decreasing one's self image-augmenting one's self-image.

H8: Hedonic quality by identification positively affects teens' satisfaction

\section{c. Hedonic quality by rational stimulation}

Hedonic quality is a subjective experience and the reason for choosing a hedonic choice will depend on the individual's characteristics (including individual perspectives about rational reasons). When people buy hedonic products, they may go through several logical stages, whether they make a transaction to take advantage of a promotion so that they can save money, or they buy products in case of uncertain conditions in the future (Higgins, 2002, Higgins, Idson, Freitas, Spiegel, \& Molden, 2003).

In the context of a café, even though hanging out at a café is about a lifestyle and hedonic choice, if the café can offer excellent service and make the teens feel they have made the right choice, the teens will be satisfied.

Internal and external justifications of hedonic choice presented by Hassenzahl et al (2003, 2005) and Poushneh and Vasquez (2017) described whether the product is either: ordinary-novel, dull-captivating, conservativeinnovative, cautious-bold, unimaginative-creative or conventional-inventive.

According to previous studies, this study proposed the following hypothesis:

H9: Hedonic quality through rational stimulation positively affects teens' satisfaction

\section{Customer Satisfaction}

Achieving customer satisfaction is a key performance measure to see whether the marketing activities are a success or failure. Customer satisfaction is a person's feeling of pleasure or disappointment which results from comparing a product's perceived performance or outcome against his/her expectations (Kotler and Keller, 2006). Achieving customer satisfaction has a big impact on customer's post purchase behavior, in the form of customer loyalty (Saleh, et al., 2015).

Yang, et al. (2010) found that service quality has an influence on online satisfaction and perceived value. This research's additional finding is that satisfaction and perceived value play an important role in customer's loyalty. Prior research found that a customer's loyalty does affect the customer's behavior including repeat purchases and good word-of-mouth advertising (Fornell, 1992; Kandampully and Suhartanto, 2000).

Skogland and Siguaw (2004) made a valuable contribution by finding that visitors' satisfaction could generate positive word-ofmouth promotion as a form of customer loyalty. This research encouraged further research into customer satisfaction in the hospitality industry, one study is by Kim and Moon (2009), who found that customer satisfaction could improve customer loyalty in the restaurant business. Recent studies of customer satisfaction in the hospitality business are by Hussein, et al. (2015); and Rauyruen and Miller (2007). Therefore the last hypothesis proposed in this study is:

H10: Teens satisfaction positively affects attitudinal loyalty

\section{Attitudinal Loyalty}

The cafe business is currently one of the most competitive markets in the hospitality industry. The numbers keep growing, despite many of them not lasting long, thus advanced strategies need to be implemented to be success in this industry, and to profit fully from it. Kotler et al (1998) stated that loyalty plays an important role in reducing the marketing costs associated with attracting new customers (Kotler 


\section{Customer Experience}

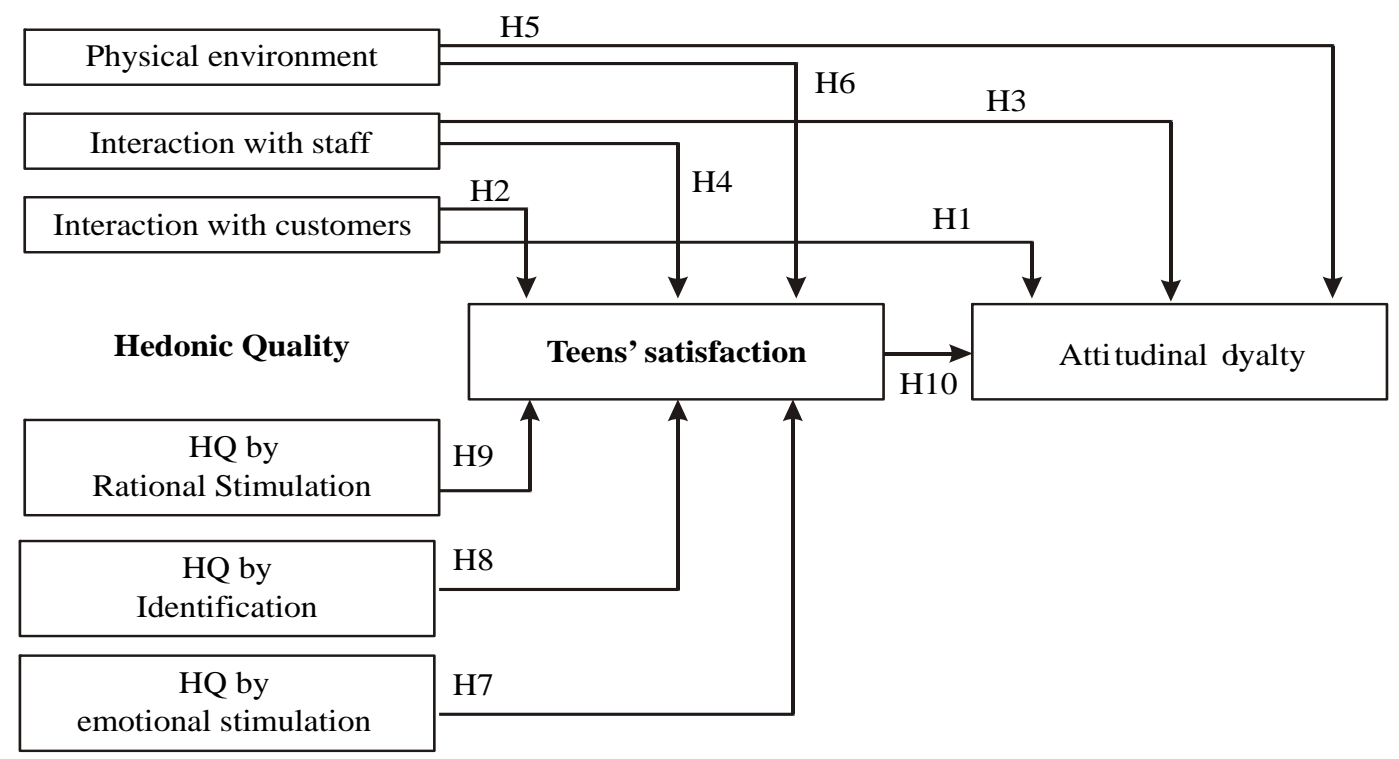

Figure 1: Research Framework

et al., 1998). Previously, Oliver (1997) described that high levels of loyalty are created when customers have positive feelings about the goods, thus customer satisfaction is the key to achieving customer loyalty.

In the hospitality industry, prior studies analyzed what customers tend to do when they have high levels of loyalty. Tepeci (1999) found that a loyal customer will say positive things about the company, previously Bowen and Shoemaker (1998) found that a loyal customer is more likely to pay a premium price for a product. Sim, et al. (2008) found loyal customers are the main profit resource in the hotel business.

In this research, we focused on attitudinal loyalty as the predictor of future behavior, rather than behavioral loyalty. Attitudinal loyalty is described as the customer's feeling and intention toward further action with the product they have consumed; meanwhile behavioral loyalty is the action of repurchasing the product (Glasman and Albarracin (2006). Prior studies used three dimensions of attitudinal loyalty, they are cognitive, affective and conative (Ajzen, 2005; Hussein, et al., 2015); and Chaudhuri and Holbrook, 2001).
RESEARCH METHOD, DATA, AND ANALYSIS

\section{Research Data}

Questionnaires were used to collect the data and were distributed to the respondents personally. Since there are a great number of teenagers in Indonesia, and because of the growing importance of the roles they play in the café business and household spending, the population of this study is Indonesian teens who have experience of hanging out at a cafe. A purposive sampling technique was chosen to select the respondents using the following criteria:

1. Teenagers aged 10-19 (adolescents). This study divided this second decade of life following the United Nations Children's Fund (2011) proposal that adolescence can be classified into two parts: early adolescence (10-14) and late adolescence (15-19).

2. Hanging out at a cafe at least once a month. Repeating this activity means the teens have loyalty, as they hang out in the same café for several times.

Two hundred respondents participated in this study. Multi-item questionnaires were developed 
by this study to attain the study's aims. Four basic questions were provided to gain information relating to the respondents' demographic details (gender, age, educational background and monthly hanging out expenses). Measurement scales were developed from the literature and previous studies. A customer experience measure was adapted from $\mathrm{Wu}$ and Liang (2009), Jani and Han (2013), and Ali et al (2016) using 13 items (physical environment five items, interaction with staff four items, and interaction with customers four items).

To measure the hedonic quality, 18 items were taken from Hassenzahl et al (2003) and Poushneh and Vasquez (2017). The customer satisfaction measure used a scale developed by Westbrook and Oliver (1991).

Lastly, this study adopted ten items for the attitudinal loyalty measure, as proposed by Jones and Taylor (2007), Hussein et al, (2015), Chaudhuri and Holbrook, (2001) and Srivastava and Kaul (2016). Measurement of all the items was calculated by using a five-point Likert scale.

\section{Research Method}

This study is an explanatory research type. SPSS 23 will be employed to find information about the characteristics of the respondents, while PLS 3 will be run to test the validity and reliability of each instrument, and to test the hypotheses of this study. The analysis follows three steps. The first step is to describe the demographic profile of the respondents by their gender, age, educational background and monthly hanging out expenses. The second is to test the convergent validity, discriminant validity and reliability (inner and outer models). Finally, for the last step, we examine the hypotheses to assess the impact of customer experience and hedonic quality on the teenagers' satisfaction and attitudinal loyalty when hanging out at a cafe.

\section{Research Analysis}

Based on the data collection, the sample could be categorized into two groups of teens: early adolescence and late adolescence

Respondents' Characteristics. According to Table 1 (Profile of Respondents), it could be concluded that the majority were male (133 respondents or $66.5 \%$ ), while there were 67 females (33.5\%). In the age group, 56 respondents (28\%) were early adolescence (10-14) and 144 respondents (72\%) were late adolescence (15-19).

Out of these 200 respondents, six respondents (3\%) were elementary students, 29 respondents (14.5\%) were junior high school students, 61 respondents (30.5\%) were senior high school students and 104 respondents (52\%) were university students.

The demographics also show the monthly hanging out expenses ranged from $<500,000$ (40 people or 20\%); 500,001 - 750,000 (55 people or $27.5 \%$ ); $750,001-1,000,000$ (63 people or $31.5 \%$ ); and $>1,000,000$ (42 people or $21 \%$ ).

The result was in line with research conducted by De Goede, Branje, and Meeus (2009) that found parental power decreased from early to late adolescence and support declined after early adolescence. In other words, parents have more power over an early adolescent, including if they let an early adolescent hang out at a cafe without the parents being there. To assess the inner and outer models, this research carried out three analyses: internal consistency reliability, convergent validity, and discriminant validity. Several criteria were used. Factor loadings for each item must be greater than 0.6 (Chin et al, 2008). Ten items were removed from this study due to them having a loading factor of less than 0.6 
Table 1. Profile of Respondents

\begin{tabular}{lccc}
\hline Profile & Description & Frequency (N) & Percentage \\
\hline Gender & Female & 67 & $33.5 \%$ \\
Male & $10-14$ & 133 & $66.5 \%$ \\
Age & $15-19$ & 56 & $28 \%$ \\
Educational & Elementary School & 144 & $72 \%$ \\
Background & Junior High School & 6 & $3 \%$ \\
& Senior High School & 29 & $14.5 \%$ \\
& University & 61 & $30.5 \%$ \\
Monthly Hanging & $<500,000$ & 104 & $52 \%$ \\
Out Expense & $500,000-750,000$ & 40 & $20 \%$ \\
& $750,001-1,000,000$ & 55 & $27.5 \%$ \\
& $>1,000,000$ & 63 & $31.5 \%$ \\
Frequency of & $1-2$ & 42 & $21 \%$ \\
Hang out at Café & $3-4$ & 128 & $64 \%$ \\
in A Month & $>4$ & 61 & $30.5 \%$ \\
Source: Data Analysis from SPSS 23, 2017 & 11 & $5.5 \%$ \\
\hline
\end{tabular}

Table 2. Discriminant Validity (outer loading)

\begin{tabular}{|c|c|c|c|c|c|c|c|c|}
\hline & \multicolumn{3}{|c|}{ Customer Satisfaction } & \multirow{2}{*}{$\begin{array}{l}\text { Attitudinal } \\
\text { Loyalty }\end{array}$} & \multirow[b]{2}{*}{ Satisfaction } & \multirow[b]{2}{*}{ HQ - I } & \multicolumn{2}{|l|}{ HQ - S } \\
\hline & PE & IS & IC & & & & $\begin{array}{l}\text { Emotional } \\
\text { stimulation }\end{array}$ & $\begin{array}{l}\text { Rational } \\
\text { stimulation }\end{array}$ \\
\hline CE1.1 & 0.710 & 0.191 & 0.230 & 0.253 & 0.388 & 0.015 & 0.203 & 0.122 \\
\hline CE1.3 & 0.627 & 0.210 & 0.191 & 0.305 & 0.254 & 0.067 & 0.159 & 0.134 \\
\hline CE1.4 & 0.822 & 0.328 & 0.149 & 0.295 & 0.405 & 0.083 & 0.288 & 0.273 \\
\hline CE1.5 & 0.818 & 0.432 & 0.237 & 0.274 & 0.427 & 0.084 & 0.302 & 0.288 \\
\hline CE2.1 & 0.376 & 0.782 & 0.307 & 0.175 & 0.310 & 0.179 & 0.213 & 0.136 \\
\hline CE2.2 & 0.285 & 0.862 & 0.312 & 0.196 & 0.360 & 0.248 & 0.226 & 0.164 \\
\hline CE2.3 & 0.301 & 0.847 & 0.337 & 0.149 & 0.323 & 0.252 & 0.205 & 0.223 \\
\hline CE2.4 & 0.309 & 0.716 & 0.396 & 0.238 & 0.365 & 0.208 & 0.177 & 0.142 \\
\hline CE3.1 & 0.207 & 0.316 & 0.702 & 0.305 & 0.202 & 0.227 & 0.131 & 0.076 \\
\hline CE3.2 & 0.263 & 0.394 & 0.827 & 0.162 & 0.267 & 0.076 & 0.073 & 0.087 \\
\hline CE3.3 & 0.175 & 0.271 & 0.815 & 0.083 & 0.274 & 0.070 & 0.036 & 0.129 \\
\hline CE3.4 & 0.200 & 0.347 & 0.810 & 0.243 & 0.329 & 0.148 & 0.207 & 0.212 \\
\hline AL1 & 0.307 & 0.208 & 0.181 & 0.716 & 0.287 & 0.303 & 0.349 & 0.256 \\
\hline AL2 & 0.200 & 0.161 & 0.260 & 0.690 & 0.187 & 0.352 & 0.262 & 0.113 \\
\hline AL3 & 0.293 & 0.169 & 0.250 & 0.745 & 0.319 & 0.264 & 0.360 & 0.207 \\
\hline AL6 & 0.318 & 0.177 & 0.173 & 0.756 & 0.347 & 0.345 & 0.388 & 0.234 \\
\hline AL7 & 0.217 & 0.146 & 0.086 & 0.707 & 0.404 & 0.342 & 0.426 & 0.348 \\
\hline AL8 & 0.231 & 0.160 & 0.197 & 0.625 & 0.340 & 0.298 & 0.458 & 0.339 \\
\hline CS1 & 0.368 & 0.311 & 0.259 & 0.227 & 0.759 & 0.222 & 0.258 & 0.383 \\
\hline CS2 & 0.376 & 0.246 & 0.173 & 0.243 & 0.733 & 0.175 & 0.233 & 0.358 \\
\hline CS3 & 0.532 & 0.312 & 0.236 & 0.393 & 0.836 & 0.205 & 0.349 & 0.388 \\
\hline CS4 & 0.315 & 0.343 & 0.280 & 0.295 & 0.783 & 0.250 & 0.306 & 0.415 \\
\hline HQ2 & 0.019 & 0.162 & 0.077 & 0.340 & 0.254 & 0.755 & 0.265 & 0.236 \\
\hline HQ3 & -0.016 & 0.168 & 0.034 & 0.265 & 0.221 & 0.749 & 0.230 & 0.250 \\
\hline HQ7 & 0.155 & 0.257 & 0.235 & 0.346 & 0.287 & 0.666 & 0.600 & 0.420 \\
\hline HQ9 & 0.096 & 0.087 & -0.026 & 0.322 & 0.302 & 0.357 & 0.705 & 0.529 \\
\hline HQ10 & 0.293 & 0.259 & 0.117 & 0.418 & 0.321 & 0.475 & 0.783 & 0.443 \\
\hline HQ11 & 0.264 & 0.229 & 0.180 & 0.441 & 0.244 & 0.437 & 0.759 & 0.411 \\
\hline HQ12 & 0.317 & 0.194 & 0.202 & 0.431 & 0.310 & 0.322 & 0.748 & 0.449 \\
\hline
\end{tabular}




\begin{tabular}{|c|c|c|c|c|c|c|c|c|}
\hline & \multicolumn{3}{|c|}{ Customer Satisfaction } & \multirow{2}{*}{$\begin{array}{l}\text { Attitudinal } \\
\text { Loyalty }\end{array}$} & \multirow[b]{2}{*}{ Satisfaction } & \multirow[b]{2}{*}{ HQ - I } & \multicolumn{2}{|l|}{ HQ - S } \\
\hline & $\mathbf{P E}$ & IS & IC & & & & $\begin{array}{l}\text { Emotional } \\
\text { stimulation }\end{array}$ & $\begin{array}{l}\text { Rational } \\
\text { stimulation }\end{array}$ \\
\hline HQ13 & 0.242 & 0.190 & 0.133 & 0.276 & 0.331 & 0.378 & 0.510 & 0.771 \\
\hline HQ14 & 0.232 & 0.153 & 0.146 & 0.252 & 0.386 & 0.265 & 0.486 & 0.796 \\
\hline HQ15 & 0.196 & 0.100 & 0.074 & 0.331 & 0.369 & 0.332 & 0.473 & 0.830 \\
\hline HQ16 & 0.273 & 0.206 & 0.165 & 0.303 & 0.394 & 0.348 & 0.553 & 0.743 \\
\hline HQ17 & 0.122 & 0.160 & 0.093 & 0.253 & 0.335 & 0.371 & 0.406 & 0.732 \\
\hline HQ18 & 0.181 & 0.110 & 0.134 & 0.197 & 0.290 & 0.237 & 0.299 & 0.603 \\
\hline
\end{tabular}

Abbreviation: CE (Customer Experience); CL (Customer Loyalty); CS (Customer Satisfaction); HQ (Hedonic Quality); HQI (Hedonic Quality by Identification); HQ-S (Hedonic Quality by Stimulation); PE (Physical Environment); IS (Interaction with Staff); IC (Interaction with Customer). Loading score of each indicator must be higher than all its cross loadings compared to other constructs. Source: PLS 3 Output, 2017

Table 3. Convergent and Reliability

\begin{tabular}{|c|c|}
\hline Variable & $\begin{array}{c}\text { Factor } \\
\text { Loadings }\end{array}$ \\
\hline $\begin{array}{l}\text { Hedonic Quality by Identification } \\
\text { (CA: } \mathbf{0 . 5 5 0} \text {;AVE: } 0.525 ; \text { CR: } 0.768 \text { ) } \\
\text { - Separates me from people-brings me closer to people } \\
\text { - Alienating-integrating } \\
\text { - Decreases one's self image-augments one's self-image }\end{array}$ & $\begin{array}{ll}\text { - } & 0.755 \\
\text { - } & 0.749 \\
\text { - } & 0.666\end{array}$ \\
\hline $\begin{array}{l}\text { Hedonic Quality by Emotional Stimulation } \\
\text { (CA: } 0.740 \text {;AVE: } 0.561 \text {; CR: } 0.836 \text { ) } \\
\text { - Repelling-appealing } \\
\text { - Discouraging-motivating } \\
\text { - Not absorbed-over absorbed } \\
\text { - Not immerse-immerse }\end{array}$ & $\begin{array}{ll}\text { - } & 0.705 \\
\text { - } & 0.783 \\
\text { - } & 0.759 \\
\text { - } & 0.748\end{array}$ \\
\hline $\begin{array}{l}\text { Hedonic Quality by Rational Stimulation } \\
\text { (CA: } 0.841 \text {; AVE: 0.562; CR: 0.884) } \\
\text { - Ordinary-novel } \\
\text { - Dull-captivating } \\
\text { - Conservative-innovative } \\
\text { - Cautious-bold } \\
\text { - Unimaginative-creative } \\
\text { - Conventional-inventive }\end{array}$ & $\begin{array}{ll}\text { - } & 0.771 \\
\text { - } & 0.796 \\
\text { - } & 0.830 \\
\text { - } & 0.743 \\
\text { - } & 0.742 \\
\text { - } & 0.603\end{array}$ \\
\hline $\begin{array}{l}\text { Physical Environment } \\
\text { (CA: } 0.734 \text {;AVE: } 0.560 \text {; CR: } 0.834) \\
\text { - The cafe's lighting is appropriate } \\
\text { - The cafe's environment is clean } \\
\text { - The cafe's architecture and setting is impressive } \\
\text { - The colors within the café are complementary and coordinated }\end{array}$ & $\begin{array}{ll}\text { - } & 0.710 \\
\text { - } & 0.627 \\
\text { - } & 0.822 \\
\text { - } & 0.818\end{array}$ \\
\hline $\begin{array}{l}\text { Interaction with Staff (Staff Performance during serving customer } \\
\text { (CA: } 0.816 \text {;AVE: } 0.647 ; \text { CR: } 0.879 \text { ) } \\
\text { - The staff provide a thorough and satisfactory service } \\
\text { - The staff are reliable } \\
\text { - The staff are professional } \\
\text { - The staff have a good knowledge }\end{array}$ & $\begin{array}{ll}- & 0.782 \\
- & 0.862 \\
- & 0.847 \\
- & 0.716\end{array}$ \\
\hline $\begin{array}{l}\text { Interaction with customers } \\
\text { (CA: } 0.800 \text {; AVE: } 0.624 \text {; CR: } 0.869) \\
\text { - Other customers are not loud } \\
\text { - Other customers behave nicely } \\
\text { - Other customers are not problematic } \\
\text { - Other customers do not create a disturbance }\end{array}$ & $\begin{array}{ll}\text { - } & 0.702 \\
\text { - } & 0.827 \\
\text { - } & 0.815 \\
\text { - } & 0.810\end{array}$ \\
\hline
\end{tabular}




\begin{tabular}{|c|c|}
\hline Variable & $\begin{array}{l}\text { Factor } \\
\text { Loadings }\end{array}$ \\
\hline $\begin{array}{l}\text { Customer Satisfaction } \\
\text { (CA: } 0.882 \text {; AVE: } 0.586 \text {; CR: 0.908) } \\
\text { - I am satisfied with my decision to visit this cafe } \\
\text { - My choice to choose this cafe was a wise one } \\
\text { - I think I did the right thing to visit this cafe } \\
\text { - I feel that my experience with this cafe has been enjoyable }\end{array}$ & $\begin{array}{ll}\text { - } & 0.759 \\
\text { - } & 0.733 \\
\text { - } & 0.836 \\
\text { - } & 0.783\end{array}$ \\
\hline $\begin{array}{l}\text { Attitudinal Loyalty } \\
\text { (CA: 0.801; AVE: } 0.501 \text {; CR: } 0.857 \text { ) } \\
\text { - I consider this cafe as my only choice for hanging out } \\
\text { - I am willing to pay more, compared to other cafes, for the products I buy from this cafe } \\
\text { - I identify with this cafe more than with any other cafe } \\
\text { - I will choose this cafe as my first choice if hanging out } \\
\text { - I will recommend hanging out in this cafe to others } \\
\text { - I am willing to revisit this cafe }\end{array}$ & $\begin{array}{rr}- & 0.716 \\
- & 0.690 \\
- & 0.745 \\
- & 0.756 \\
- & 0.707 \\
0.625 & \end{array}$ \\
\hline $\begin{array}{l}\text { breviation : CA (Cronbach Alpha); AVE (Average Variance Extracted): CR (Composite Reliability) } \\
\text { urce }\end{array}$ & \\
\hline
\end{tabular}

After shorting the items, a PLS algorithm was run for a second time to make sure that all the items had a loading factor of greater than 0.6 (tables 2 and 3). The next step was the discriminant validity. Table 3 depicts good discriminant validity as the loading score of each indicator is higher than for all its cross loadings, compared to the other constructs.

Moreover, Table 3 revealed the convergent validity and the reliability of the measurements. Cronbach's alpha for all the variables were higher than 0.6 (Hair et al., 2010). It indicates that all the variables had good reliability, except for the hedonic quality by identification. According to Table 3 the hedonic quality by identification had a Cronbach's alpha of $<0.6$, but other assessments of this variable showed a good model fit, so this study decided to keep hedonic quality by identification as a variable

The convergent validity of the constructs (Table 2) were good, as the factor loadings of each indicator were higher than 0.6 (Chin et al., 2008), the average variance extracted was greater than 0.5 (Hair, 2006), and the composite reliability score was higher than 0.6 (Hair et al, 2011).

For the inner model's analysis, this study used the $\mathrm{R}^{2}$ endogenous latent variables, predictive relevance/ $\mathrm{Q}^{2}$; and Goodness of Fit (GoF).

Table 4 presents the substantial $\mathrm{R}^{2}$ endogenous latent variables with $\mathrm{Q}^{2}$ which is 0.583 .

Table 4. R-square

\begin{tabular}{ll}
\hline \multicolumn{1}{c}{ Variable } & \multicolumn{1}{c}{ R-square } \\
\hline Attitudinal Loyalty & 0.244 \\
Satisfaction & 0.449 \\
\hline
\end{tabular}

Source: PLS 3 Output

Predictive relevance $\left(\mathrm{Q}^{2}\right)$ :

$$
\begin{aligned}
& \mathrm{Q}^{2}=1-\left[\left(1-R_{1}^{2}\right) \times\left(1-R_{2}^{2}\right)\right. \\
& \mathrm{Q}^{2}=1-[(1-0.244) \times(1-0.449)] \\
& \mathrm{Q}^{2}=1-(0.756) \times(0.551) \\
& \mathrm{Q}^{2}=0.583
\end{aligned}
$$

Goodness of Fit (GoF):

$$
\begin{aligned}
& \mathrm{GoF}=\sqrt{\overline{A V E} \times \overline{R^{2}}} \\
& \mathrm{GoF}=0.444707629(0.445)
\end{aligned}
$$

The Goodness of Fit (GoF) of the study is 0.445 . It means this study has a very good model (Tenenhaus et al., 2005). The result also refers to Hoffmann and Birnbrich's (2012) cut-off values for assessing the results of the GoF analysis, which can be classified into three categories: $\mathrm{GoF}=0.1$ (small); $\mathrm{GoF}=0.25$ (medium); and $\mathrm{GoF}=0.36$ (large). 
Table 5. Path Coefficients

\begin{tabular}{lcccccl}
\hline \multicolumn{1}{c}{ Hypotheses } & $\begin{array}{c}\text { Original } \\
\text { Sample (0) }\end{array}$ & $\begin{array}{c}\text { Sample } \\
\text { Mean (M) }\end{array}$ & $\begin{array}{c}\text { Standard } \\
\text { Deviation } \\
\text { (STDEV) }\end{array}$ & T Statistics & P Values & Summary \\
\hline IC -> TL & 0.109 & 0.103 & 0.101 & 1.079 & 0.281 & Not Supported (H1) \\
IC -> TS & 0.123 & 0.131 & 0.056 & 2.179 & 0.030 & Supported (H2) \\
IS -> TL & -0.022 & -0.023 & 0.083 & 0.264 & 0.792 & Not Supported (H3) \\
IS -> TS & 0152 & 0.155 & 0.065 & 2.328 & 0.020 & Supported (H4) \\
PE -> TS & 0.187 & 0.192 & 0.088 & 2.135 & 0.033 & Supported (H5) \\
PE -> TL & 0.321 & 0.316 & 0.063 & 5.113 & 0.000 & Supported (H6) \\
HQ-S (Emotional)- > TS & -0.016 & -0.005 & 0.088 & 0.176 & 0.860 & Not Supported (H7) \\
HQ-I - > TS & 0.158 & 0.158 & 0.068 & 2.313 & 0.021 & Supported (H8) \\
HQ-S (Rational)- > TS & 0.272 & 0.274 & 0.067 & 4.057 & 0.000 & Supported (H9) \\
TS -> TL & 0.332 & 0.341 & 0.076 & 4.351 & 0.000 & Supported (H10) \\
\hline if P $<0$ 05
\end{tabular}

if $\mathrm{P}<0.05$ and $\mathrm{T}$ statistic $>1.96$, hypotheses was accepted

Source: PLS 3 Ouput, 2017

The inner model's analysis shows a good model fit for this study, and can be used for the hypotheses testing.

After the inner and outer models' analyses, bootstrapping was run to assess the proposed hypotheses. Hair (2014) and Kock (2012) determined if the P score is less than 0.05 (< 0.05 ) and the $T$ statistic values are greater than 1.96 (>1.96), then the hypotheses will be accepted. In contrast, if the $\mathrm{P}$ score is greater than 0.05 (> 0.05) and the T statistic values are lower than $1.96(<1.96)$, it means the hypotheses will be rejected (Hair, 2014 and Kock, 2012).

The result of the hypotheses testing is presented in Table 4. It depicted that out of the ten hypotheses proposed in this study, seven hypotheses were supported (accepted), since $\mathrm{P}<$ 0.05 and the T statistic $>1.96$.

In general, the results of this study support those obtained in the previous studies about hedonic quality, customer experience, satisfaction and attitudinal loyalty. The findings outlined in this study found that customer experience, including its three dimensions (staff interaction, guest interaction, and physical environment), has a significant effect on satisfaction. Interestingly, there is only one dimension of customer expe- rience (namely the physical environment) that has an impact on loyalty (interaction with staff and other customers have no influence on loyalty).

In addition, the findings also provide empirical evidence that the hedonic quality by identification and the hedonic quality by rational stimulation have a strong effect toward satisfaction. On the other hand the impact of hedonic quality by emotional stimulation to satisfaction is rejected. Moreover, according to this study, satisfaction was confirmed to have an effect on attitudinal loyalty.

\section{DISCUSSION}

Seven out of the ten hypotheses proposed by this research were accepted, according to the testing using smartPLS 3 (Table 5). The first notable result from this study is the role of customer experiences' influence toward customer satisfaction and attitudinal loyalty. Teenagers are able to quickly recognize a new cafe in their area and have proved to have different experiences with each cafe. The results from this study support the findings from Teng (2011); Collins (2010); Jalil, et al. (2016); and Ali, et al. (2016).

This study found that in the cafe business, the experience is generated by three dimensions: 
the physical environment, the interaction with staff and the interaction with customers. Additionally, we successfully constructed the items of a café's physical environment that produce this experience; they are its lighting, and the design of its layout for both the interior and exterior of the cafe. From the three dimensions proposed, all of them have an influence on satisfaction, but it is only the physical environment that affects teenage customers' attitudinal loyalty.

The strong influence of the physical environment toward attitudinal loyalty is recognized as a result of the social media trends among the younger generation. Teenage customers are more likely to be satisfied if the cafes can provide a good physical environment to take pictures of themselves and their friends, which will be posted to their social media. Thus, the cleanliness and the interior and exterior design of the cafe are highly valued by the teenage customers. Additionally, there are some intangible elements, such as music and the scenic view, which is provided by the location of the café, that should be considered by the owner and manager of the cafe (Jensen and Hansen, 2007; and Hemmington, 2007)

Despite the interaction with other customers, and the interaction with staff, having no significant effect on attitudinal loyalty, they still should be considered because these two elements of a customer's experience have a significant effect on the customer's satisfaction. Moreover, prior studies (Lashley, 2008; Brotherton, 2005; O’Connor, 2005; and Telfer, 2000) indicated that building satisfaction by creating positive experiences would generate loyalty. The prior findings also give a chance for a future researcher to explore the mediating role of customer satisfaction in the relationship between the three elements of customer experiences and loyalty.
By keeping the hospitality of their employees focused on the customers (welcoming staff, warm, sincere, friendly and appropriate service), teens feel more satisfied. A café might consider have signs that show the importance of keeping conducive behavior ever-present and respecting each other, or providing special rooms for customers who like more privacy. This all relates to the finding that interaction with other customers influences teens' satisfaction.

In this study, among the three elements of customer experience, the interaction with staff and the interaction with other customers have no significant effect on teens' attitudinal loyalty, while the physical environment has a strong effect on teens' attitudinal loyalty. Perhaps the reason for this findings is due to the main motivation for teens to go and hang out, which is for them to find a cozy place to socialize and to show their existence, whether in the real world, or the virtual world by posting their activities (Arnold and Reynolds, 2003; Babin, et al, 1994; and Wakefield and Baker, 1998). It means teens will be satisfied with good service from cafe staff and a conducive situation among the café's customers, but these factors are not enough to make them willing to recommend the café's services to others, or think they will revisit the cafe.

It would be different if teens feel satisfied with the physical environment of the cafe. They will share their hang out experiences by taking pictures, giving them interesting captions and posting them to their social media. Teens will also be able to inform others of their location by using the check-in menu on facebook, instagram or any other form of social media.

Studies have proven that activities on social media will contribute to attitudinal loyalty (Castronovo and Huang, 2012; Brodie et al., 2013). By offering a good physical environment 
(unique spots, interesting layout and so on), the popularity of a cafe will increase as more teens share photos on social media when they are at the cafe. The more popular the café gets, the more teens want to be part of the trend and the more willing they are to revisit it and to recommend it to others. Hence, this study expects a further study to validate these findings

The second finding of this research is the role of customer hedonic quality, which is proven to be important because it has a significant effect toward customer satisfaction. This finding supports prior studies, such as those by Gallarza and Saura, (2006); Berry and Wall, (2007); Kim and Moon, (2009); Pullman and Gross, (2004); Pullman and Robson, (2007); Ryu and Jang, (2007); Magnini and Parker, (2009).

Hedonic quality is proposed to have a higher value for the customer than utility (Dhar and Wertenbroch, 2000; Diefanbach and Hassenzahl, 2011; and Okada, 2005). This research found that the hedonic quality by identification and rational stimulation could affect teens' satisfaction, but the emotional stimulation does not.

A non-significant effect of hedonic quality by emotional stimulation on teens' satisfaction might be contributed by teen characteristics; although, this finding is rarely found in the marketing literature. Being moody is one teen characteristic that is caused by hormonal changes during puberty (Vulliamy, 2016). A teenager's mood can change rapidly. It means that a teen's emotional experiences are complex, and it is difficult for them to be a satisfied customer. Teens tend to adjust to other factors to gain their satisfaction.

Chaet (2012) stated that teens tend to be ambitious, opinionated, and influential. These characteristics also support the findings of this study. Even though teens feel happy and enjoy their time in a café, it does not guarantee they feel really satisfied. Their feeling of satisfaction is influence by others (friends and family) and others' opinions.

These facts bring new insights that a café manager may consider, to provide goods and services that are authentic, to use buzz marketing, and to offer unique products (Schiff, 2007; Goodstein, 2007).

The need for self-expression from the teenage customer is considered to be the strongest reason why it has a strong effect on satisfaction. This finding should encourage cafe owners and managers to make their cafes exclusive, to improve the self-confident of the customers when visiting their cafes. Solomon (1999) found that one motive for why consumers visit a famous restaurant is so that they gain a certain position among other people inside and outside their social circle.

The second dimension of hedonic quality that affects satisfaction is the rational stimulation. This finding has proved that there is a uniqueness that a customer looks for from the cafe they visit. If the cafe has the following attributes, such as it is unique, new, adorable, bold, creative, and innovative, the cafe is more likely to satisfy its visitors, especially the teenagers. Teens have the intention of trying something that is new and coherent with their personality. By analyzing the trends of teenagers in their area, a cafe's owner or manager should be able to determine what theme their cafes should try.

Holbrook (1999); Jones, et al (2006); Chadon, et al. (2000); and Deb (2012) previously found that a hedonic customer tends to be satisfied by the following attributes: themed environments, unique events and contests, various food courts, an entertaining game zone, nice music, a good aroma, comfortable seating space, and the overall atmosphere. They conclude that fulfilling these hedonic 
aspects is valued higher than any utilitarian aspect for the customer.

Lastly, this research finds that customer satisfaction has a significant effect on attitudinal loyalty. This finding is commonly found in the prior research (Hussein, et al., 2015; and Rauyruen and Miller, 2007). Achieving customer satisfaction is the key to creating customer loyalty, thus owners and managers of cafes should be able to maintain and improve their customers' satisfaction in order to achieve attitudinal loyalty.

\section{CONCLUSION}

Fast growth in the customer food services' market is considered here because of the rising demand triggered by the changing community lifestyles and consumption patterns. One of the most influential customer groups that are reshaping the market is the teenage group. Despite the high demand in the market, the competition is difficult since they are facing a different generation that have a strong influence on their families' purchasing behavior.

Achieving and maintaining long-term customer relationships is considered to be the first priority of a company (Oliver, 1980; and Zeithaml et al., 1996). In order to achieve that goal, a company must fulfill its customers' needs and make sure the customer is satisfied with their goods and services. Unfortunately, there are only a few recent studies into teenage customers' behavior, especially in the hospitality industry.

This research is proposed to analyze key variables that could affect teenage customers' satisfaction and attitudinal loyalty. As suggested by Collins (2010), the atmosphere of a cafe is considered to have an effect toward customer satisfaction and loyalty. A café's atmosphere is one dimension of a customer's experience; therefore we collected previous research about customers' experiences and found a new experience quality for cafe visitors. Additionally we included the hedonic quality as a determinant of customer satisfaction and attitudinal loyalty.

Seven out of our ten hypotheses are accepted with the help of the SmartPLS 3 application. The physical environment and the interaction of customers and staff are found to have an influence toward customer satisfaction; furthermore the physical environment can generate customer satisfaction. Additionally the customers' hedonic quality dimensions have a significant effect toward customer satisfaction, but hedonic quality by emotional stimulation does not.

The results of this research make several academic contributions, such as the teenage customers' experience constructs which are: the physical environment and the interaction between the staff and with the other customers. This research also provides a variable construct for the hedonic quality of cafe visitors.

Empirically, this research provides an insight into how teenage satisfaction and attitudinal loyalty is generated. The physical environment is considered to be the key factor that contributes to both satisfaction and attitudinal loyalty; meanwhile we suggest that cafe owners and managers should make sure their employees maintain a good service quality for their customers. Additionally, a new cafe owner or manager should be encouraged to do market research and a consumer analysis before creating a new cafe. This approach is considered important because one of the hedonic qualities that is valued by the teenage generation is the novelty and uniqueness of a cafe. 


\section{MANAGERIAL IMPLICATION, RESEARCH LIMITATION, AND FUTURE RESEARCH}

Teenagers are considered to be the new influencers of domestic purchasing; therefore analyzing the factors that could affect their satisfaction and attitudinal loyalty is considered important for achieving and maintaining customer satisfaction, and thus generating attitudinal loyalty. This research specifically analyzes factors that could affect teenage customers' satisfaction and attitudinal loyalty with cafes. The results of the research should encourage cafe owners and managers to consider altering and improving their cafe's physical environment, in order to achieve customer satisfaction and generate their loyalty Additionally, a good cafe should have its own novel and unique aspects, so it will attract new customer to the cafe.

Despite the theoretical and empirical contribution provided by this research, we need to evaluate our model. In the near future we should analyze the mediating role of customer satisfaction in the relationship between customer experience and hedonic quality toward customer attitudinal loyalty,

We suggest that future research explores any remaining variables that could affect teenage customers' satisfaction and attitudinal loyalty, including the brand image, brand personality, self congruity, and perceived quality The fast development of technology is creating a gap between the generations, and that is one reason why the newer generation is unique and needs further research to analyze its behavior. Additionally we encourage future researchers to build different construct for the variables included in this research if they apply the model to different industries.

\section{ACKNOWLEDGEMENTS}

The financing of the research by Brawijaya University is gratefully acknowledged.

\section{REFERENCES}

Ajzen., (2005). Attitudes, personality, and behaviour. McGraw-Hill International. Available at http://www.google.co.id/ books?hl=en\&lr=\&id=dmJ9EGEy0ZYC\&p gis $=1$

Ali, F., K. Ryu, and K. Hussain., 2015. Creative tourists' experience, memories, satisfaction and behavioural intentions. Journal of Travel and Tourism Marketing, 33(1), 85100.

Ali, F., W.G. Kim., J. Li., and H. M. Jeon., 2016. Make it delightful: Customers' experience, satisfaction, and loyalty in Malaysian Theme Parks. International Journal of Destination Marketing \& Management.

Apfel, I., (1998). Tourism shakes up new business. Restaurant USA, 18 (1), 22-25.

Ariffin, H., M. Bibon., and R. Abdullah., (2012). Restaurant's atmospheric elements: What the customer wants. Social and Behavioral Sciences, (38), 380-387.

Arnold, M. J. and K.E. Reynolds., (2003). Hedonic shopping motivations. Journal of Retailing, 79, 77-95.

Assael, H., (2004), Consumer behavior: A strategic approach, $6^{\text {th }}$. Ed Boston, MA: Houghton Mifflin Company.

Astuti, S., \& Hanan, H. (2012). The behaviour of consumer society in consuming food at restaurants and cafes. Procedia-Social and Behavioral Sciences, 42, 429-435.

Babin, B. J., Darden, W. R., \& Griffin, M. (1994). Work and/or fun: Measuring hedonic and utilitarian shopping value. Journal of Consumer Research, 20(4), 644656.

Bellini, J, (2016). The no 1 thing to consider before opening a restaurant. Available at 
https://www.cnbc.com/2016/01/20/heresthe-real-reason-why-most-restaurantsfail.html

Berry, L.L., and Wall E.A., (2007). The combined effects of the physical environment and employee behavior on customer perception of restaurant service quality. Cornell Hotel and Restaurant Administration Quarterly, 48 (1), 59-69.

Bigné, J. E., Andreu, L., \& Gnoth, J. (2005). The theme park experience: An analysis of pleasure, arousal and satisfaction. Tourism Management, 26(6), 833-844.

Bitner, M., (1992). Services capes: The impact of the physical surroundings on customers and employees. Journal of Marketing, 56(2), 57-71.

Bowen, J. and Shoemaker, S., (1998). Loyalty: A strategic commitment. Cornell Hotel and Restaurant Administration Quarterly, 39 (1), 12-25.

Brady,M.K., \& Cronin,J.J., (2001). Some new thoughts on conceptualizing perceived service quality: A hierarchical approach. Journal of Marketing, 65(3), 34-49.

Brodie, R. J., Ilic, A., Juric, B., \& Hollebeek, L. (2013). Consumer engagement in a virtual brand community: An exploratory analysis. Journal of Business Research, 66(1), 105114.

Brotherton, B. (2005). The nature of hospitality: Customer perceptions and implications. Tourism and Hospitality Planning \& Development, 2(3), 139-153.

Castronovo, C. and Huang, L. (2012). Social media in an alternative marketing communication model. Journal of Marketing Development \& Competitiveness, 6, 117136.

Cetin, G., \& Dincer, F.I., (2014). Influence of customer experience on loyalty and wordof-mouth in hospitality operations. Anatolia: An International Journal of Tourism and Hospitality Research, 25(2), 181-194.
Chaet, H. (2012). The tween machine. Adweek, June, 25, 44-47.

Chandon, P., B. Wansibk., and G. Laurent., (2000). A benefit congruency framework of sales promotion effectiveness. J. Mark, 64 (4), 65-81.

Chaudhuri, A., \& Holbrook, M. B. (2001). The chain of effects from brand trust and brand affect to brand performance: The role of brand loyalty. Journal of marketing, 65(2), 81-93.

Chilkoti, A., (2016). Indonesia's aspiring coffee kings. Available at: https://www.ft.com/ content/ca663fb8-20e2-11e6-9d4dc11776a5124d.

Chin, W. W., Peterson, R. A., \& Brown, S. P. (2008). Structural equation modeling in marketing: Some practical reminders. Journal of Marketing Theory and Practice, 16(4), 287-298.

Chitturi, R., Raghunathan, R., \& Mahajan, V. (2008). Delight by design: The role of hedonic versus utilitarian benefits. Journal of Marketing, 72(3), 48-63.

Collins, G. R., (2010). Usable mobile ambient intelligent solutions for hospitality customers. Journal of Information Technology Impact, 10(1), 45-54.

De Goede, I. H., Branje, S. J., \& Meeus, W. H. (2008). Developmental changes in adolescents' perceptions of relationships with their parents. Journal of Youth and Adolescence, 38(1), 75-88. doi:10.1007/ s10964-008-9286-7

Deb, M. (2012). Evaluation of customer's mall preferences in India using fuzzy AHP approach. Journal of Advances in Management Research, 9(1), 29-44.

Desmet, P. M., \& Hekkert, P., (2007). Framework of product experience. International Journal of Design, 1(1), 57-66.

Dhar, R., \& Wertenbroch, K. (2000). Consumer choice between hedonic and utilitarian goods. Journal of Marketing Research, 37(1), 60-71. 
Diefenbach, S., \& Hassenzahl, M. (2011). The dilemma of the hedonic-Appreciated, but hard to justify. Interacting with Computers, 23(5), 461-472.

Dugan, E., (2015). 16 to 24-year-olds spend more on food than any other age group, says research. Available at http://www.independent.co.uk/news/uk/hom e-news/16-to-24-year-olds-spend-more-onfood-than-any-other-age-group-saysresearch-a6678596.html

Feloni, Richard., (2014). Food network chef robert irvine shares the top reasons restaurants fail. Available at http://www.businessinsider.com/whyrestaurants-fail-so-often-2014-2/?IR=T

Fisk, A. D., W. Rogers., N. Charness., S. J. Czaja, and J. Sharit., (2004). Designing for older adults: Principles and creative human factors approaches. London, U.K: Taylor and Francis.

Fornell, C. (1992). A national customer satisfaction barometer: The Swedish experience. Journal of Marketing, 56(1), 6-21.

Gallarza, M. G., \& Saura, I. G. (2006). Value dimensions, perceived value, satisfaction and loyalty: An investigation of university students' travel behaviour. Tourism Management, 27(3), 437-452.

Glasman, Laura R., and Dolores Albarracin. Forming attitudes that predict future behavior: A meta-analysis of the attitudebehavior relation. Psychological Bulletin 132, no. 5 (2006): 778. Doi:http//dx.doi.org/ 10.1037/0033-2909.132.5.778.Goodstein,

A. (2007). Teen marketing: Apple's the master. Bloomberg Businessweek. http://www. businessweek. Com/augus2007.

Griffin, J., \& Herres, R. T. (2002). Customer loyalty: How to earn it, how to keep it (p. 18). San Francisco, CA: Jossey-Bass.

Grove, S. J., Fisk, R. P., \& Dorsch, M. J. (1998). Assessing the theatrical components of the service encounter: A cluster analysis examination. Service Industries Journal, 18(3), 116-134.
Guest, L., (1955). Twelve years later. Journal of Applied Psychology, vol. 39, pp. 405-408.

Gupta, S, and Vajic, M. eds., (1999). The contextual and dialectical nature of experiences in: J. Fitzsimmons, \& $M$. Fitzsimmons, New service development. Thousand Oaks, CA: Sage.

Hair, J.F., B. Black., B. Babin., R.E. Anderson., and R.L Tatham., (2010). Multivariate data analysis. $7^{\text {th }}$ ed. Englewood A Liffs, NJ: Prentice Hall.

Hair, J.F., B. Black., B. Babin., R.E. Anderson., and R.L Tatham., (2006). Multivariate data analysis. Upper Saddle River, NJ: PrenticeHall.

Hair, J.F., C.M. Ringle., and M. Sarstedt., (2011). PLS-SEM: Indeed a silver bullet. Journal of Marketing Theory and Practice, 19(2), 139-151.

Hair, J.f., T.M. Hult., C.M. Ringle., and M. Sarstedt., (2014). A primer on partial least squares structural equation modeling (PLSSEM). Los Angeles: SAGE.

Hartson R, \& Pyla, P. S. (2012), The ux book: Process and guidelines for ensuring $a$ quality user experience. Roumeliotis R, Bevans D, editors. Waltham, MA, USA: Morgan Kaufmann (Elsevier); 2012.

Hassenzahl, M., (2005). The thing and $i$ : Understanding the relationship between user and product. Funology: From usability to enjoyment, 31-42.

Hassenzahl, M., \& Tractinsky, N. (2006). User experience-a research agenda. Behaviour \& Information Technology, 25(2), 91-97.

Hassenzahl, M., Burmester, M., \& Koller, F. (2003). AttrakDiff: Ein Fragebogen zur Messung wahrgenommener hedonischer und pragmatischer Qualität. In Mensch \& computer 2003 (pp. 187-196). Vieweg+ Teubner Verlag.

Hassenzahl, M., (2008). User experience (UX): Towards an experiential perspective on product quality. In Proc. of the 20th International Conference of the Association 
Francophone D'interaction HommeMachine. IHM '08, vol. 339. (2008) ACM, New York, NY, 11-15.

Hemmington, N. (2007). From service to experience: Understanding and defining the hospitality business. The Service Industries Journal, 27(6), 747-755.

Higgins, E. T. (2002). How self-regulation creates distinct values: The case of promotion and prevention decision making. Journal of Consumer Psychology, 12(3), 177-191.

Higgins, E. T., Idson, L. C., Freitas, A. L., Spiegel, S., \& Molden, D. C. (2003). Transfer of value from fit. Journal of Personality and Social Psychology, 84(6), 1140-1153.

Holbrook, M. B., \& Hirschman, E. C. (1982). The experiential aspects of consumption: Consumer fantasies, feelings, and fun. Journal of Consumer Research, 9(2), 132140.

Holbrook, M. B. (Ed.). (1999). Consumer value: a framework for analysis and research. Psychology Press. Routledge: London

Hosany, S., \& Witham, M. (2009). Dimensions of cruisers experience satisfaction, intention to recommend. Journal of Travel Research, 1-14.

Huang, J., \& Hsu, C. H. (2010). The impact of customer-to-customer interaction on cruise experience and vacation satisfaction. Journal of Travel Research, 49(1), 79-92.

Hussein, A. S., Ismail, T., \& Hapsari, R. (2015). The formation of brand loyalty in Indonesian restaurant industry. European Journal of Tourism, Hospitality and Recreation, 6(2), 67-98.

Internet World Stats., (2017). The world population and the top ten countries with the highest population. Available at: http://www.internetworldstats.com/stats8.ht $\mathrm{m}$

Jacoby, J., (1971). Brand loyalty: A conceptual definition. Proceedings, 79th American
Psychological Association Convention, pp. 655-656

Jalil, N. A. A., Fikry, A., \& Zainuddin, A. (2016). E-atmospheric effects on youth intention to revisit a cafe. Procedia Economics and Finance, 37, 497-503.

Jani, D., \& Han, H. (2013). Personality, social comparison, consumption emotions, satisfaction, and behavioral intentions: How do these and other factors relate in a hotel setting?. International Journal of Contemporary Hospitality Management, 25(7), 970993.

Jensen, Ø., \& Hansen, K. V. (2007). Consumer values among restaurant customers. International Journal of Hospitality Management, 26(3), 603-622.

Jiang, Y., \& Lu Wang, C. (2006). The impact of affect on service quality and satisfaction: the moderation of service contexts. Journal of Services Marketing, 20(4), 211-218.

Jones, M. A., Reynolds, K. E., \& Arnold, M. J. (2006). Hedonic and utilitarian shopping value: Investigating differential effects on retail outcomes. Journal of Business Research, 59(9), 974-981.

Jones, T., \& Taylor, S. F. (2007). The conceptual domain of service loyalty: How many dimensions?. Journal of Services Marketing, 21(1), 36-51.

Josiam, B. M., \& Henry, W. (2014). Eatertainment: Utilitarian and hedonic motivations for patronizing fun experience restaurants. Procedia-Social and Behavioral Sciences, 144, 187-202.

Josiam, B. M., Mattson, M., \& Sullivan, P. (2004). The Historaunt: Heritage tourism at Mickey's dining car. Tourism Management, 25(4), 453-461.

Kakar, A. K. S. (2017). Why do users prefer the Hedonic but choose the Utilitarian? Investigating user dilemma of HedonicUtilitarian choice. International Journal of Human-Computer Studies, 108, 50-61.

Kandampully, J., \& Suhartanto, D. (2000). Customer loyalty in the hotel industry: The 
role of customer satisfaction and image. International Journal of Contemporary Hospitality Management, 12(6), 346-351.

Kao, Y. F., Huang, L. S., \& Wu, C. H. (2008). Effects of theatrical elements on experiential quality and loyalty intentions for theme parks. Asia Pacific Journal of Tourism Research, 13(2), 163-174.

Kesari, B., \& Atulkar, S. (2016). Satisfaction of mall shoppers: A study on perceived utilitarian and hedonic shopping values. Journal of Retailing and Consumer services, 31, 22-31.

Kim, W. G., \& Moon, Y. J. (2009). Customers' cognitive, emotional, and actionable response to the servicescape: A test of the moderating effect of the restaurant type. International Journal of Hospitality Management, 28(1), 144-156.

Kim, W. G., Li, J. J., \& Brymer, R. A. (2016). The impact of social media reviews on restaurant performance: The moderating role of excellence certificate. International Journal of Hospitality Management, 55 (5), 41-51.

Kock, N. (2012). WarpPLS 3.0 user manual. Laredo, TX: ScriptWarp Systems.

Kotler, P., J. Bowen, and J. Makens., (1998). Marketing for hospitality and tourism. Englewood A Liffs, N J: Prentice Hall

Lashley, C. (2008). Studying hospitality: insights from social sciences. Scandinavian Journal of Hospitality and Tourism, 8(1), 69-84.

Lashley, C., Morrison, A., \& Randall, S., (2005). More than a service encounter? Insights into the emotions of hospitality through special meal occasions. Journal of Hospitality and Tourism Management, 12 (1), 80-92.

Loureiro, S. M. (2010). Satisfying and delighting the rural tourists. Journal of Travel \& Tourism Marketing, 27(4), 396-408.

Lugosi, P., Robinson, R. N., Golubovskaya, M., \& Foley, L. (2016). The hospitality consumption experiences of parents and carers with children: A qualitative study of foodservice settings. International Journal of Hospitality Management, 54, 84-94.

Magnini, V. P., \& Parker, E. E. (2009). The psychological effects of music: Implications for hotel firms. Journal of Vacation Marketing, 15(1), 53-62.

Mary. M, A. Lenhart, S. Cortesi, U. Gasser, M. Duggan, A. Smith., (2013). Teens, social media, and privacy. Available At http://www.pewinternet.org/2013/05/21/teen s-social-media-and-privacy/, accessed on December $25^{\text {th, }} 2017$

Mossberg, L. (2007). A marketing approach to the tourist experience. Scandinavian Journal of Hospitality And Tourism, 7(1), 59-74.

O'Connor, D. (2005). Towards a new interpretation of "hospitality". International Journal of Contemporary Hospitality Management, 17(3), 267-271.

O’Dell, Brandon., (2008). The biggest mistakes restaurants make, and why they have a high failure rate. available at https://blog.bodellconsulting.com/2008/03/2 9/the-biggest-mistakes-restaurants-makeand-why-they-have-a-high-failure-rate/

Okada, E. M. (2005). Justification effects on consumer choice of hedonic and utilitarian goods. Journal of Marketing Research, 42(1), 43-53.

Oliver, R. L. (1980). A cognitive model of the antecedents and consequences of satisfaction decisions. Journal of Marketing Research, 17(4), 460-469.

Oliver, R. L, (1997). Satisfaction: A behavioral perspective on the consumer. Boston, MA: McGraw-Hill.

Peterson, Harley., (2017). Teens have a new favorite restaurant-and it's not Starbucks. Available at http://www.businessinsider.sg/how-teensare-spending-money-2017-4/?r=US\&IR=T

Pine, B. J., \& Gilmore, J. H. (1998). Welcome to the experience economy. Harvard Business Review, 76, 97-105. 
Poushneh, A., \& Vasquez-Parraga, A. Z. (2017). Discernible impact of augmented reality on retail customer's experience, satisfaction and willingness to buy. Journal of Retailing and Consumer Services, 34, 229-234.

Pullman, M. E., \& Gross, M. A. (2004). Ability of experience design elements to elicit emotions and loyalty behaviors. Decision Sciences, 35(3), 551-578.

Pullman, M. E., \& Robson, S. K. (2007). Visual methods: Using photographs to capture customers' experience with design. Cornell Hotel and Restaurant Administration Quarterly, 48(2), 121-144.

Ruggless, Ron., (2017). Teen food spending hits new high. Available at http://www.nrn.com/consumer-trends/teenfood-spending-hits-new-high

Ryu, K., Lee, H. R., \& Gon Kim, W. (2012). The influence of the quality of the physical environment, food, and service on restaurant image, customer perceived value, customer satisfaction, and behavioral intentions. International Journal of Contemporary Hospitality Management, 24(2), 200-223.

Ryu, K., \& Han, H. (2011). New or repeat customers: how does physical environment influence their restaurant experience?. International Journal of Hospitality Management, 30(3), 599-611.

Ryu, K., \& Jang, S. S. (2007). The effect of environmental perceptions on behavioral intentions through emotions: The case of upscale restaurants. Journal of Hospitality \& Tourism Research, 31(1), 56-72.

Saleh, M.A.H., A. Althonayan., A. Alhabib., E. Alrasheedi, and G. Alqahtani., (2015). Customer satisfaction and brand switching intention: A study of mobile services in Saudi Arabia. Expert Journal of Marketing, 3 (2), 62-72

Sánchez, J., Callarisa, L., Rodriguez, R. M., \& Moliner, M. A. (2006). Perceived value of the purchase of a tourism product. Tourism Management, 27(3), 394-409.
Schiff, J. (2007). How to market to teens: Keep it real and simple. http://www.ecommerceguide.com, retrived: 10/7/2012.

Serkan, A., O. Göekhan., and A. Öemer., (2005). Customer loyalty and the effect of switching costs as a moderator variable: A case in the Turkish mobile phone market. Marketing Intelligence and Planning, 23(1), 89-103

Seyhmun Baloglu., (2002). Dimensions of customer loyalty: Separating friends from well wishers. Cornell Hotel and Restaurant Administration Quarterly, 43(1), 47-59.

Sim, J., Mak, B., \& Jones, D. (2008). A model of customer satisfaction and retention for hotels. Journal of Quality Assurance in Hospitality \& Tourism, 7(3), 1-23.

Skogland, I., \& Siguaw, J. A. (2004). Are your satisfied customers loyal?. Cornell Hotel and Restaurant Administration Quarterly, 45(3), 221-234.

Slåtten, T., Krogh, C., \& Connolley, S. (2011). Make it memorable: customer experiences in winter amusement parks. International Journal of Culture, Tourism and Hospitality Research, 5(1), 80-91.

Solomon, M.R., (1999). The value of status and the status of value. In: Holbrook, M.B. (Ed.), Consumer Value: A Framework for Analysis and Research. Routledge, London; New York.

Srivastava, M., \& Kaul, D. (2016). Exploring the link between customer experience-loyaltyconsumer spend. Journal of Retailing and Consumer Services, 31, 277-286.

Telfer, E., Eds., (2000). The philosophy of hospitableness. In: Lashley, C., Morrison, A. In search of hospitality: Theoretical perspectives and debates. ButterworthHeinemann: Oxford.

Teng, C. C. (2011). Commercial hospitality in restaurants and tourist accommodation: Perspectives from international consumer experience in Scotland. International Journal of Hospitality Management, 30(4), 866-874. 
Tepeci, M. (1999). Increasing brand loyalty in the hospitality industry. International Journal of Contemporary Hospitality Management, 11(5), 223-230.

Tombs, A. G., \& McColl-Kennedy, J. R. (2013). Third party customers infecting other customers for better or for worse. Psychology \& Marketing, 30(3), 277-292.

United Nation., (2015). Youth population trends and sustainable development. Available at http://www.un.org/esa/socdev/documents/yo uth/fact-sheets/YouthPOP.pdf

United Nations Children's Fund., (2011). The state of the world's children 2011. Available at: https://www.unicef.org/ adolescence/files/SOWC_2011_Main_Repo rt_EN_02092011.pdf.

Vulliamy, Elsa., (2016). Why are teenagers so moody? Available at

https://www.independent.co.uk/news/scienc e/why-are-teenagers-so-moodya6874856.html.

Wakefield, K. L., \& Baker, J. (1998). Excitement at the mall: determinants and effects on shopping response. Journal of Retailing, 74(4), 515-539.

Walls, A., Okumus, F., Wang, Y., \& Kwun, D. J. W. (2011). Understanding the consumer experience: An exploratory study of luxury hotels. Journal of Hospitality Marketing \& Management, 20(2), 166-197.

Westbrook, R. A., \& Oliver, R. L. (1991). The dimensionality of consumption emotion patterns and consumer satisfaction. Journal of Consumer Research, 18(1), 84-91.

Widiadana., (2017). Adolescent summit to address teen pregnancy. Available at: http://www.thejakartapost.com/news/2017/0 3/21/adolescent-summit-address-teenpregnancy.html, accessed on May 25 ${ }^{\text {th }}, 2017$

Wu, C. H. J., \& Liang, R. D. (2009). Effect of experiential value on customer satisfaction with service encounters in luxury-hotel restaurants. International Journal of Hospitality Management, 28(4), 586-593.

Yang, H.E., W.-J. Cheng, J.-Y. Chan, B.-C. Pan, and C.-S. Chia., (2010, April). Applying an extended ES-Qual scale to assess the effects of e-service quality on online loyalty with customer satisfaction and perceived value as mediators. In Proceedings of the 9th WSEAS international conference on Applied computer and applied computational science (pp. 55-59). World Scientific and Engineering Academy and Society (WSEAS).. Hangzhou China. Available at http://www.wseas.us/elibrary/conferences/2010/Hangzhou/ACAC OS/ACACOS-08.pdf

Zeithaml, V. A., Berry, L. L., \& Parasuraman, A. (1996). The behavioral consequences of service quality. Journal of Marketing, 60(2), 31-46.

Zeithaml, V.A., Bitner, M.J., \& Gremler, D.D., (2006). Service marketing: Integrating customer focus across the firm (4th ed.).NewYork,NY: McGraw-Hill. 